\title{
Correlation between neuropathic pain and quality of life
}

\author{
Correlação entre dor neuropática e qualidade de vida
}

Flavia Cesarino Almeida' ${ }^{1}$ Amanda Castilho², Claudia Bernardi Cesarino', Rita de Cassia Helu Mendonça Ribeiro', Marielza Regina Ismael Martins ${ }^{2}$

DOI 10.5935/2595-0118.20180066

\section{ABSTRACT}

BACKGROUND AND OBJECTIVES: Neuropathic pain is a complex, painful condition, difficult to diagnose and treat with a negative impact on patients' health and quality of life. The objective of this study was to evaluate the correlation between pain and quality of life, identifying the limiting aspects in the daily life of these individuals, so that patient education is recommended in the management of this condition.

METHODS: This is a descriptive, cross-sectional study conducted in a Pain Clinic with 61 patients diagnosed with neuropathic pain. The tools used to assess the quality of life were a semi-structured interview, the Douleur Neuropathique 4 Questions questionnaire, and the World Health Organization Quality of Life-BREF.

RESULTS: Of the patients, $57.3 \%$ were women, average age $50.6 \pm 13.12$ years. As for the educational level, 59\% attended elementary school, and 61\% were married. In 39\%, diseases were the main causes of pain and physical problems as the main changes after pain (57\%). The majority of patients had a positive attitude towards neuropathic pain (68\%). The physical domain was the most impaired in quality of life. All the domains of the quality of life assessment instrument had Cronbach's alpha coefficients $(<0.700)$ with average adherence, especially the general domain, with Cronbach's alpha negative (-0.055).

CONCLUSION: Knowing the aspects of the impact of pain on patients' quality of life comes to be a useful scientific resource in the clinical practice and encourages a model of educational intervention where the client is the main subject in managing their painful condition.

Keywords: Chronic pain, Education, Quality of life.

\footnotetext{
1. Faculdade de Medicina de São José do Rio Preto, Departamento de Enfermagem, PósGraduação de Enfermagem, São José do Rio Preto, SP, Brasil.

2. Faculdade de Medicina de São José do Rio Preto, São José do Rio Preto, SP, Brasil.

Submitted on March 12, 2018.

Accepted for publication on September 17, 2018

Conflict of interests: none - Sponsoring sources: Bolsa de Iniciaçấo Cientifica CNPq.

Correspondence:

Avenida Faria Lima, 5416 - Vila São Pedro

15090-000 São José do Rio Preto.

E-mail: marielzamartins@famerp.br

(C) Sociedade Brasileira para o Estudo da Dor
}

\section{RESUMO}

JUSTIFICATIVA E OBJETIVOS: A dor neuropática é uma condição dolorosa complexa, de difícil diagnóstico e tratamento, que causa um impacto negativo na saúde e qualidade de vida dos pacientes. $\mathrm{O}$ objetivo deste estudo foi avaliar a correlaçáo entre a dor e a qualidade de vida, identificando os aspectos limitantes no cotidiano desses indivíduos para que a educação do paciente seja recomendada no gerenciamento dessa condição.

MÉTODOS: Trata-se de um estudo descritivo, transversal, realizado em uma Clínica da Dor, com 61 pacientes de diagnóstico clínico de dor neuropática. Foram utilizados uma entrevista semiestruturada, o questionário sobre dor neuropática Douleur Neuropathique 4 Questions e, para avaliar a qualidade de vida o questionário World Health Organization Quality of Life-BREF.

RESULTADOS: Dos pacientes avaliados, 57,3\% eram mulheres, média de idade 50,6 $\pm 13,12$ anos. Quanto ao nível educacional $59 \%$ frequentaram o ensino fundamental e, 61\% eram casados. Em 39\%, as doenças foram as principais causas de dor e, os problemas físicos como as principais mudanças após a dor (57\%). A maioria dos pacientes apresentou atitude positiva em relação à dor neuropática (68\%), o domínio físico foi o mais comprometido na qualidade de vida. Todos os domínios do instrumento de avaliação da qualidade de vida apresentaram coeficientes alfa de Cronbach $(<0,700)$ com média aderência, especialmente o domínio geral, com alfa de Cronbach negativo $(-0,055)$.

CONCLUSÁO: Conhecer os aspectos do impacto da dor na qualidade de vida dos pacientes apresenta-se como um recurso científico útil na prática clínica em saúde e estimula um modelo de intervenção educativa onde o paciente seja o principal sujeito do gerenciamento da sua condição dolorosa.

Descritores: Dor crônica, Educação, Qualidade de vida.

\section{INTRODUCTION}

Neuropathic pain (NP) occurs as a direct consequence of a disease or injury that affects the somatosensory system ${ }^{1}$ and that should have the diagnosis based on the description of the pain by the patient and other subjective symptoms (burns, cracks, shocks, etc.), assessment of clinical signs, and laboratory tests that demonstrate such alterations ${ }^{2}$.

Data from the literature vary but reported a prevalence of NP around $8 \%$ of the general population, probably due to the methodology used and the instruments for diagnosis. In Latin America, NP affects 2\% of the population, and 15 patients out of 100 who seek medical help for pain suffer from $\mathrm{NP}^{2,3}$. 
The assessment of the patient should focus on the degree of impairment of the somatosensory system, neurological deficits, comorbidities of the limbic system and cognition, and finally, on the general impact of pain on health and quality of life (QoL) of patients ${ }^{3}$.

Studies show that chronic neuropathic pain may contribute to disability, depression, anxiety, sleep disorders, poor QoL and increased health care costs, with about $20 \%$ of the adult population in Europe $e^{4,5}$ compromised.

Recent studies have shown that most patients treated for NP receive drugs of undetermined efficacy or underdosed, with tricyclic antidepressants and anticonvulsants drugs being the main representatives in the treatment of this type of pain, whether peripheral or central origin ${ }^{6,7}$.

One factor that interferes with the study of NP prevalence is the method used to make the diagnosis. Several criteria are currently used, and the most used instruments have been the Douleur Neuropathique 4 Questions (DN4) questionnaires and especially the Leeds Assessment of Neuropathic Symptoms and Signs Score (S-LANSS) that aim to identify predominantly pain of neuropathic origin, as distinct of nociceptive pain, without the need for clinical examination. The S-LANSS questionnaire was recently validated for use in postal surveys, making identification of pain of predominantly neuropathic origin easier and more feasible. Another instrument is the painDETECT (PD-Q) questionnaire, a reliable screening instrument with high sensitivity, specificity and a positive predictive value around $80 \%{ }^{8,9}$.

It is noted that in recent surveys, non-pharmacological and psychoeducational methods for the management of pain are increasingly being used; which demonstrates a new vision of professionals.

Nevertheless, these studies are scarce in Brazil, and in the international literature, although appearing more frequently. It is observed that educational interventions produce significant positive effects on the function and knowledge of patients with pain ${ }^{10}$.

Thus, it is advisable to enable the person to self-manage, and education and training on the nature of pain and its effects have demonstrated that the use of self-care educational intervention in patients with NP improves QoL, independence, and vitality ${ }^{11}$. Given this context, this study aimed to assess the correlation between pain and QoL, identifying limiting aspects in the daily life of these patients.

\section{METHODS}

This is a descriptive, cross-sectional study performed at the Pain Clinic of the Base Hospital of São José do Rio Preto, with patients clinically diagnosed with NP, on mean $15 \pm 2.3$ months. Patients with mental retardation, neurological disease or who did not consent to participate in the study were excluded.

A semi-structured interview was used to collect the sociodemographic data of patients with neuropathic pain and the DN4 ${ }^{12}$ pain questionnaire, originally in French, which was duly translated and validated into Portuguese and was used to identify patients with non-neuropathic and neuropathic pain. The questionnaire consists of 10 items subdivided into two parts: sensorial descriptors (seven items) and signs related to sensory examination (three items). The presence of NP was considered the dependent variable and necessary to achieve a score of at least 4 in 10, while non-neuropathic pain presented scores lower than 4 in 10.

In order to assess the QoL, the WHOQOL-bref ${ }^{13}$ questionnaire was used, consisting of 26 questions divided into 4 domains: physical, psychological, social relations and the environment. This instrument is recommended by the World Health Organization (WHO) because it values individual perception and can assess the QoL in several groups and situations, regardless of the level of education. The instrument has satisfactory psychometric properties and requires little application time. Through this instrument, it is possible to describe the subjective perception of an individual in relation to his/her physical and psychological health, social relations and the environment in which he/she live ${ }^{13,14}$.

Sampling was of convenience, and the calculation of its size considered the population of 70 patients attended monthly in the Service of the Pain Clinic. The study sample was calculated by the online sample calculator, considering a $95 \%$ confidence interval and an error margin of 55 , totaling 61 patients.

These data were collected by a previously trained researcher, prior to the medical appointment, and his/her telephone contacts were recorded for future self-management research.

This study was approved with Opinion n. 2,024,585 by the FAMERP Ethics and Research Committee.

\section{Statistical analysis}

The statistical analysis used the t-test in the comparison of the QoL instrument scores and the Variance Analysis (ANOVA) test with a post-hoc Tukey multiple comparison test to compare the QoL instrument scores and pain, in addition to the alpha analysis of Cronbach for correlations. The level of significance applied to the tests: 0.05 or $5 \%$ and the software used was Minitab 17 (Minitab Inc.).

\section{RESULTS}

61 patients were assessed: $57.3 \%(\mathrm{n}=35)$ women, mean age $50.6 \pm 13.1$ years old and median age 51 years old. The coefficient of variation (CV) of this distribution was $25.9 \%$. The minimum age observed was 21 years, and the maximum age was 74 years. As for educational level, $59 \%(\mathrm{n}=36)$ attended only elementary school and 61\% ( $\mathrm{n}=37)$ were married. It was reported in 39\% $(n=24)$ diseases as being the main cause of pain and, reporting physical problems as the main changes after pain $(57 \%-\mathrm{n}=35)$. Most patients presented a positive attitude towards NP $(68 \%$ $\mathrm{n}=42$ ) (Table 1).

All patients had NP confirmed by DN4. When considering the aspects involved in this questionnaire, the pain intensity was $5.1 \pm 1.2$, and the most prevalent sensory descriptors were tingling $(52 \%)$ and burning (28\%). Regarding the physical signs related to sensitivity, hypoesthesia to the touch was the predominant one (62\%).

Regarding QoL, table 2 shows the results of the WHOQOL-BREF application for patients with NP.

In this study, the physical domain was the one with the lowest score when compared to the other domains, show- 
Table 1. Percentage of sample characterization variables of patients with neuropathic pain assessed in the study. São José do Rio Preto/ SP, 2017

\begin{tabular}{|c|c|c|}
\hline \multirow[t]{2}{*}{ Variables } & \multicolumn{2}{|c|}{ Patients with neuropathic pain } \\
\hline & $\mathrm{n}$ & $\%$ \\
\hline \multicolumn{3}{|l|}{ Gender } \\
\hline Female & 35 & 57.38 \\
\hline Male & 26 & 42.62 \\
\hline \multicolumn{3}{|l|}{ Education } \\
\hline Elementary school & 36 & 59.02 \\
\hline High school & 15 & 24.59 \\
\hline Higher education & 10 & 16.39 \\
\hline \multicolumn{3}{|l|}{ Marital status } \\
\hline With partner & 37 & 61.67 \\
\hline Without a partner & 23 & 38.33 \\
\hline \multicolumn{3}{|l|}{ Cause of pain } \\
\hline Accident & 16 & 26.23 \\
\hline Diseases & 24 & 39.34 \\
\hline Others & 16 & 26.23 \\
\hline Do not know & 5 & 8.20 \\
\hline \multicolumn{3}{|l|}{ Changes after pain } \\
\hline Emotional problems & 26 & 42.62 \\
\hline Physical problems & 35 & 57.38 \\
\hline \multicolumn{3}{|l|}{ How they deal with pain } \\
\hline Negative attitude & 19 & 68.85 \\
\hline Positive attitude & 42 & 31.15 \\
\hline
\end{tabular}

Table 2. Descriptive statistics of quality of life scores of patients with neuropathic pain by the World Health Organization Quality of Life-BREF. São José do Rio Preto/SP, 2017

\begin{tabular}{|c|c|c|c|c|}
\hline Domain & $n$ & $\begin{array}{l}\text { Mean } \pm \text { standard } \\
\text { deviation }{ }^{2}\end{array}$ & Median age & $P$ value ${ }^{1}$ \\
\hline General & 61 & $49.18 \pm 17.66 \mathrm{ab}$ & 50.00 & $<0.001$ \\
\hline Physical & 61 & $43.74 \pm 14.60 \mathrm{~b}$ & 46.43 & \\
\hline Psychological & 61 & $55.33 \pm 15.50 \mathrm{a}$ & 54.17 & \\
\hline Social & 61 & $56.69 \pm 18.56 \mathrm{a}$ & 58.33 & \\
\hline Environment & 61 & $55.58 \pm 12.57 \mathrm{a}$ & 56.25 & \\
\hline
\end{tabular}

${ }^{1 P}$ value for the Variance Analysis (ANOVA) test at $p<0.05 .{ }^{2}$ Different letters in the same column are differentiated by the Tukey multiple comparison test at $p<0.05$.

ing that the patients assessed had significantly lower QoL in this domain. Thus, this domain will be analyzed according to the sample characterization variables in order to observe the influence of these variables on the physical domain score (Table 3).

The results of table 3 showed that there are no significant differences in the physical domain scores for the sample characterization variables assessed.

As for correlations, the Cronbach alpha parameter was used, which indicates the adherence of the sample to the applied QOL instrument, showing the high or low reliability of the instrument to measure the QoL of the study subjects. Table 4 shows the Cronbach's alpha coefficients for patients with NP.
Table 3. Descriptive statistics of physical domain scores according to the World Health Organization Quality of Life-BREF for patients with neuropathic pain. São José do Rio Preto/SP, 2017

\begin{tabular}{|c|c|c|c|c|}
\hline Descriptive statistics & $\mathrm{n}$ & $\begin{array}{c}\text { Mean } \pm \text { standard } \\
\text { deviation }\end{array}$ & $\begin{array}{l}\text { Median } \\
\text { age }\end{array}$ & $\begin{array}{c}\mathrm{P} \\
\text { value }\end{array}$ \\
\hline \multicolumn{5}{|l|}{ Gender } \\
\hline Female & 35 & $44.69 \pm 13.23$ & 46.43 & 0.570 \\
\hline Male & 26 & $42.45 \pm 16.45$ & 44.64 & \\
\hline \multicolumn{5}{|l|}{ Age group (years old) } \\
\hline Up to 59 & 44 & $45.62 \pm 13.23$ & 46.43 & 0.157 \\
\hline 60 or more & 17 & $38.87 \pm 17.17$ & 42.86 & \\
\hline \multicolumn{5}{|l|}{ Marital status } \\
\hline With partner & 38 & $44.08 \pm 13.19$ & 42.86 & 0.827 \\
\hline Without partner & 23 & $43.17 \pm 16.99$ & 46.43 & \\
\hline \multicolumn{5}{|l|}{ Education } \\
\hline Elementary school & 36 & $44.15 \pm 15.32$ & 44.64 & 0.888 \\
\hline High school & 15 & $42.14 \pm 17.03$ & 46.43 & \\
\hline Higher education & 10 & $44.64 \pm 7.19$ & 44.64 & \\
\hline \multicolumn{5}{|l|}{ Cause of pain } \\
\hline Accident & 16 & $49.33 \pm 12.73$ & 50.00 & 0.344 \\
\hline Disease & 24 & $40.92 \pm 16.14$ & 42.86 & \\
\hline Others & 16 & $42.41 \pm 15.20$ & 42.86 & \\
\hline Do not know & 5 & $43.57 \pm 6.87$ & 46.43 & \\
\hline \multicolumn{5}{|l|}{ Changes after pain } \\
\hline Emotional problems & 26 & $44.23 \pm 13.13$ & 44.64 & 0.817 \\
\hline Physical problems & 35 & $43.37 \pm 15.79$ & 46.43 & \\
\hline \multicolumn{5}{|l|}{ How you deal with pain } \\
\hline Negative attitude & 19 & $40.04 \pm 13.07$ & 42.86 & 0.165 \\
\hline Positive attitude & 42 & $45.41 \pm 15.10$ & 46.43 & \\
\hline
\end{tabular}

${ }^{*} \mathrm{P}$ value for the t-test for independent samples at $p<0.05$.

Table 4. Cronbach's alpha coefficients for the World Health Organization Quality of Life-BREF instrument domains for patients with neuropathic pain. São José do Rio Preto/SP, 2017

\begin{tabular}{lccc}
\hline Domains & $\begin{array}{c}\text { Scale/ } \\
\text { item }\end{array}$ & $\begin{array}{c}\text { Cronbach alpha } \\
\text { coefficient with } \\
\text { item exclusion }\end{array}$ & $\begin{array}{c}\text { Cronbach's alpha } \\
\text { coefficient of the } \\
\text { scale }\end{array}$ \\
\hline General & 1 & - & -0.055 \\
& 2 & - & 0.492 \\
& 3 & 0.493 & \\
& 4 & 0.445 & \\
Psychological & 10 & 0.506 & \\
& 15 & 0.430 & \\
& 16 & 0.362 & \\
& 17 & 0.484 & \\
& 18 & 0.433 & \\
& 6 & 0.455 & \\
& 7 & 0.441 & \\
& 11 & 0.358 & \\
& 19 & 0.470 & \\
26 & 0.487 & \\
\hline
\end{tabular}


Table 4. Cronbach's alpha coefficients for the World Health Organization Quality of Life-BREF instrument domains for patients with neuropathic pain. São José do Rio Preto/SP, 2017 - continuatio

\begin{tabular}{lccc}
\hline Domains & $\begin{array}{c}\text { Scale/ } \\
\text { item }\end{array}$ & $\begin{array}{c}\text { Cronbach alpha } \\
\text { coefficient with } \\
\text { item exclusion }\end{array}$ & $\begin{array}{c}\text { Cronbach's alpha } \\
\text { coefficient of the } \\
\text { scale }\end{array}$ \\
\hline Social & 20 & 0.469 & 0.475 \\
& 21 & 0.043 & \\
Environmental & 22 & 0.557 & 0.546 \\
& 8 & 0.524 & \\
& 12 & 0.517 & \\
& 13 & 0.551 & \\
& 14 & 0.536 & \\
& 23 & 0.453 & \\
& 24 & 0.477 & \\
& 25 & 0.535 & \\
\hline
\end{tabular}

\section{DISCUSSION}

A survey conducted by the USP School of Nursing in $2015^{15}$ aimed to know the implications of NP in the QoL of individuals with traumatic spinal cord injury. Unlike the results of this study, the patients participating in the survey were mostly males, aged between 30 and 49 years, married, retired and complete high school education. The implications of patients with NP and QoL show that patients who reported higher pain intensity had a worse outcome in relation to QoL in the social factor, which addresses personal relationships, sexual life, and support received from friends $s^{15}$.

A study of the probable prevalence of NP in the USA ${ }^{16}$, with a total of 24,925 interviewees, the demographic data showed $52.2 \%$ of females with an average age of 51.5 years, corroborating the data of this study.

Other authors ${ }^{16}$ found that even when living with NP, patients have a positive attitude, seeking a better QoL, but that is directly proportional to the intensity of the pain, that is, the higher the pain, the lower the QoL of the individual.

In this context, a recent survey ${ }^{17}$ reports that people with chronic pain are not passive. They actively try to change the causes of pain and their own behavior in response to pain. However, for many patients, such a change without therapeutic help is unattainable, and repeated misguided attempts to resolve the pain problem lead them further into a cycle of pain, depression, and disability.

One study assessed the impact of trigeminal neuralgia on QoL and its association with time of pain $^{18}$ in 20 patients over 40 years old, divided into 2 groups. Group I was formed by $10 \mathrm{pa}-$ tients with trigeminal neuralgia and group II by 10 healthy, painless patients. It was concluded that trigeminal neuralgia exerts a negative impact on QoL, regardless of the intensity of the pain. In a study that sought to identify the NP using the DN4, it showed that it presents itself as a validated tool for tracking ${ }^{19}$. In this survey, the item "tingling" was the most reported by those who reported pain (52\%), followed by "burning" (36.5\%) as the most reported complaint, and of the "pinched and needles" (35.4\%) and "numbness" (31.2\%). These results are in agreement with what is predicted in the literature, which points to tingling, numbness, burning, continuous pain, lacerating and pinched sensation as clinical manifestations of $\mathrm{NP}^{19}$.

Epidemiological studies on the prevalence of chronic neuropathic pain in patients' daily life report that chronic NP (NeP-Neuropathic Pain) can significantly reduce QoL and impose economic burdens on individuals and society. In these studies, there is strong evidence and suggest that patients with $\mathrm{NeP}$ experience worse health-related QoL levels than the general population ${ }^{15,19}$. All domains of the QoL assessment instrument had Cronbach's alpha coefficients below 0.700 , especially the general domain, with Cronbach's alpha negative. Thus, with a coefficient of around 0.4 and 0.5 , the instrument used (WHOQOL-BREF) showed a medium adhesion of patients with neuropathic pain. It is worth mentioning that the use of certain previously validated and general questionnaires can lead to this type of result since they are not specific for certain types of patients, that is, they are not ad-hoc. In a survey conducted in Sáo Luís, $\mathrm{MA}^{20}$, which assessed the influence of chronic pain on the QoL of the elderly, the WHOQOL-BREF presented good internal consistency. By the values observed by Cronbach's alpha coefficient in all its questions, it was possible to show the negative influence of chronic pain on the QoL of these elderlies.

The studies agree to show that chronic pain is related to the decrease in QoL, affecting autonomy and daily, social, family and financial activities ${ }^{17,19}$.

\section{CONCLUSION}

It was found that patients with NP had the QoL affected with the greatest impact on physical problems after the onset of pain and presented a positive attitude towards it, trying to change the causes of pain, but with therapeutic help.

\section{REFERENCES}

1. Rocha CE, Martins MR, Foss MH, Santos Junior R, Dias LC, Forni JE, et al. Improving quality of life of neuropathic pain patients by continuous outpatient setting monitoring. Rev Dor. 2011;12(4):291-6

2. Didangelos T, Doupis J, Veves A. Painful diabetic neuropathy: clinical aspects. Handb Clin Neurol. 2014;126:53-61.

3. Torrance N, Lawson KD, Afolabi E, Bennett MI, Serpell MG, Dunn KM, et al. Estimating the burden of disease in chronic pain with and without neuropathic characteristics: does the choice between the EQ-5D and SF-6D matter? Pain. 2014;155(10):1996-2004.

4. Dueñas M Ojeda B, Salazar A, Mico JA, Failde I. A review of chronic pain impact on patients, their social environment and the health care system. J Pain Res. 2016;9:457-67.

5. Finnerup NB, Attal N. Pharmacotherapy of neuropathic pain: time to rewrite the rulebook? Pain Manag. 2016;6(1):1-3.

6. Peyron R. Functional brain imaging: what has it brought to our understanding of neuropathic pain? A special focus on allodynic pain mechanisms. Pain. 2016;157(Suppl 1):S67-71.

7. Vase L, Skyt I, Hall KT. Placebo, nocebo, and neuropathic pain. Pain. 2016;157(Suppl 1):S98-105.

8. Stavros K, Simpson DM. Understanding the etiology and management of HIV-associated peripheral neuropathy. Curr HIV/AIDS Rep. 2014;11(3):195-201.

9. Dermanovic Dobrota V, Hrabac P, Skegro D, Smiljanic R, Dobrota S, Prkacin I, et al. The impact of neuropathic pain and other comorbidities on the quality of life in patients with diabetes. Health Qual Life Outcomes. 2014;12:171. 
10. Cardoso MG, Weinstock JG, Sardá Júnior J. Adesão ao tratamento da dor neuropática. Rev Dor. 2016;17(Suppl 1):S107-9.

11. Smith BH, Torrance N. Epidemiology of neuropathic pain and its impact on quality of life. Curr Pain Hedache Rep. 2012;16(3):191-8.

12. Santos JG, Brito JO, de Andrade DC, Kaziyama VM, Ferreira KA, Souza I, et al. Translation to Portuguese and validation of the Douleur Neuropathique 4 questionnaire. J Pain. 2011;11(5):484-90.

13. Fleck MP, Louzada S, Xavier M, Chachamovich E, Vieira G, Santos L, et al. [Aplication of the Portuguese version of the abbreviated instrument of quality life WHOQOL- bref]. Rev Saude Publica. 2000;34(2):178-83. Portuguese.

14. Cunha LL, Mayrink WC. Influência da dor crônica na qualidade de vida em idosos. Rev Dor. 2011;12(2):120-4.

15. Perissinotti DM, Portnoi AG. Aspectos psicocomportamentais e psicossociais dos portadores de dor neuropática. Rev Dor. 2016;17(Suppl 1):S79-84.
16. van Hecke O, Austin SK, Khan RA, Smith BH, Torrance N. Neuropathic pain in the general population: a systematic review of epidemiological studies. Pain. 2014;155(4):654-62.

17. Martins MR, Cunha A, Forni JN, Santos Junior R, Dias L, Araújo Filho G. Auto percepção da qualidade de vida e identificaçăo da alexitimia em pacientes com síndrome da falha cirúrgica. Rev Dor. 2017;18(1):23-6.

18. Posso IP, Palmeira CC, Vieira EB. Epidemiology of neuropathic pain. Rev Dor. 2016;17(Suppl 1):S11-4.

19. Celik S, Yenidunya G, Temel E, Purisa S, Uzum AK, Gulum N, et al. Utility of DN4 questionnaire in assessment of neuropathic pain and its clinical correlations in Turkish patients with diabetes mellitus. Prim Care Diabetes. 2016;10(4):259-64.

20. de Moraes Vieira EB, Garcia JB, da Silva AA, Mualem Araújo RL, Jansen RC. Prevalence, characteristics, and factors associated with chronic pain with and without neuropathic characteristics in São Luís, Brazil. J Pain Symptom Manage. 2012;44(2):239-51. 